\title{
Purifikasi Islam dalam Gerakan Padri di Minangkabau
}

\author{
Haedar Nashir \\ Pengurus Pusat Muhammadiyah \\ haedarnashir@yahoo.co.id
}

The Padri Movement, also known as the White Group Movement, grown up in Minangkabau in 1821 - 1837, on one side, had been a strong and militant struggle against Dutch colonization in Sumatra. On the other side, this movement also raised as a power of reform, bringing together a strong and militant mission of Islamic Purification. This movement had raised a violence controversy, both when it conflicted with traditional power and when it expanded its areas of movement to the Batak Land. In the perspective of Sociology, both the Padri Movement and its militant and violence actions brought in every expanded social or religious movement cannot be separated one and each other. This is caused by the fact that such a movement is closely related to a strict religious ideology and faith, and at once it also closely related to a complicated sociological condition at that time. Therefore, a multi-perspective is necessary to understand complicated socio-religious movements.

Keywords: Padri Movement, Religious Movement, Islamic Purification.

\section{Pandahuluan}

G erakan Padri yang terjadi di Minangkabau (1821-1837) masih menyisakan persoalan seputar implikasi atau efek gerakan ini terutama dalam melakukan tindakan-tindakan kekerasan, khususnya ketika terjadi perluasan gerakan ini ke wilayah Tanah Batak pada tahun 1816. Gugatan dialamatkan pada tindakan kekerasan yang dilakukan tentara Padri terhadap penduduk setempat. Tindakan kekerasan tersebut sering dikaitkan dengan paham kaum Padri yang juga sering disebut sebagai Kaum Putih yang bermadzhab Hambali atau Wahhabi, sehingga dipertautkan dengan paham Islam untuk pemurnian beragama yang bersifat keras.

Mangaradja Onggang Parlindungan menulis buku Tuanku Rao yang terbit tahun 1964 dan dicetak ulang tahun 2007 dengan penuh kontroversi. Penulis melukiskan "Gerakan Islam Kaum Putih Di Minangkabau" yang dipelopori Tuanku Nan Rentjeh, Tuanku Imam Bonjol, Tuanku Rao, dan lain-lain dalam "gerakan Wahhabi" dan "gerakan Paderi" terutama ketika pengiriman pasukan Padri ke Tanah Batak (Tapanuli) dan Negeri Sembilan (Malaya) sebagai "agression" (agresi) dan "teror" (Parlindungan, 2007). Buku tersebut pada bab 10 membahas Gerakan Islam Kaum Putih di Minangkabau, bab 11 tentang Tentara Padri Mengislamkan Tanah Batak Selatan 1816, dan bab 12 tentang Tentara Padri Menduduki Toba dan Silindung, 18181820. Karya yang oleh penulisnya disebut Buku Sejarah tersebut banyak menyoroti sisi negatif dari gerakan Padri.

Belakangan, pada tahun 2007, Basyral Hamidy Harahap menulis buku Greget Tuanku Rao. Menurut penulisnya buku itu 
UNISIA, Vol. XXXI No. 69 September 2008

dimaksudkan untuk mengoreksi yang salah dan hal-hal yang luput serta tidak diketahui oleh Mangaradja Onggang Parlindungan. Barsyal dalam pengantarnya ketika membahas bab tentang Datu Bange, mengungkapkan rasa greget-nya (berdebar jantung) karena harus menulis dalam bukunya tentang apa yang dialami leluhurnya di Tanah Batak akibat serangan Padri. Basyral Hamidy Harahap secara terus terang menulis sebagai berikut:

"Sebagai penulis, ada debar-debum jantung saya ketika menulis bab Datu Bange di dalam buku ini. Bukan hanya bercerita tentang kebiadaban, genocide, dan dendam yang membara. Tetapi karena ia juga bercerita tentang leluhur saya yang terus menerus melakukan perlawanan, sekalipun mereka sudah dalam posisi yang tidak menguntungkan. Sementara itu pasukan berbaju Putih yang mendengung-dengungkan agama, sambil menebas kepala manusia, membakari kampung, memperkosa, dan melakukan segala macam kebiadaban, terus mengejar musuhnya. Inilah yang membuat pihak Belanda jadi meleleh, dan terusik rasa kemanusiaannya. Datu Bange dan rombongannya terus melakukan perlawanan. Secara spontan pasukan Belanda kemudian melindungi rombongan Datu Bange. Karena jika tidak demikian, sebuah tragedi kemanusiaan yang jauh lebih kejam pasti terjadi, yang bagaimanapun tidak akan bisa diterima manusia beradab!!!." (Harahap, 2007).

Buya Hamka, ketika dipenjara (27 Januari 1964 sampai 23 Januari 1966) mengkaji buku Parlindungan yang kontroversial itu dengan seksama dan tahun 1971 lahirlah buku sanggahan berjudul Antara Fakta Dan Khayal Tuanku Rao. Buku tersebut kemudian diterbitkan ulang atas kerjasama Pemerintah Daerah Kabupaten Pasaman dan Majalah/Penerbit Suara Muhammadiyah menjelang Seminar tentang Tuanku Imam Bonjol dan Tuanku Rao pada bulan Desember tahun 2008 ini. Buya Hamka setelah mempelajari buku Parlindungan tersebut menyatakan secara lugas, bahwa, "setelah saya pelajari buku itu berbulan-bulan dengan sangat seksama, maka saya sampai pada kesimpulan: \pm $80 \%$ dari isi buku itu adalah tidak benar, dan secara agak kasar boleh disebut dusta" (Hamka, 2007: 1).

Persoalan yang selama ini masih menjadi kontroversi mengenai gerakan Padri dalam hubungannya dengan ekspansi ke Tanah Batak tampaknya akan terus menggelayut menjadi wacana kesejarahan. Lebih-lebih dengan sudut pandang dan subjektivitas yang satu sama lain berbeda dalam mengkajinya. Para ahli sejarah atau ilmu sosial tentu dapat mengkajinya secara lebih menyeluruh dengan menggunakan perspektivisme, yakni dari berbagai sudut pandang secara interkoneksitas sehingga diperoleh gambaran yang lebih objektif, luas, dan lengkap. Namun betapapun luas, lengkap, dan objektifnya kajian ilmu sosial tentang sejarah yang telah terjadi di masa lampau tentu selalu terdapat keterbatasan dan relativitas sebagaimana pada umumnya watak ilmu. Hal yang tidak kalah pentingnya, bagaimana semua anak bangsa dapat belajar dari sejarah dengan cerdas, arif, dan sambil menatap masa depan dengan penuh kedewasaan demi perjalanan hidup yang harus lebih baik.

Kajian ini ingin melihat aspek purifikasinya yang dikaitkan dengan paham Wahhabi yang mewarnai gerakan Padri di Ranah Minangkabau. Bagaimana memahami dalam arti menjelaskan gejala paham keagamaan dalam Islam itu, sehingga sering menimbulkan konflik dan 
Purifikasi Islam dalam Gerakan Padri...; Haedar Nashir

kadang kekerasan, terutama dalam situasi krisis terjadi. Kekerasan yang dipertautkan dengan perilaku keagamaan memang merupakan persoalan klasik, yang sering terjadi hingga zaman kontemporer saat ini. Pada umumnya kekerasan dalam bentuk apapun seringkali tidak merupakan tindakan tunggal, sering kali berkaitan dengan berbagai aspek sosiologis yang kompleks.

\section{Kajian Pustaka}

\section{Gerakan Keagamaan}

Mengkaji suatu gerakan sebagaimana studi tentang gerakan Padri termasuk di dalamnya ketokohan Tuanku Imam Bonjol, Tuanku Rao, dan tokoh-tokoh sejarah yang menyertai gerakan yang begitu menonjol di Minangkabau dengan berbagai wajahnya yang beragam memang harus ditelaah secara menyeluruh dan tidak parsial. Hal demikian karena setiap gerakan sosial, lebih-lebih gerakan keagamaan yang bersifat meluas tidaklah hadir di ruang vakum atau kosong. Setiap gerakan sosial termasuk di dalamnya gerakan keagamaan selalu memiliki banyak sisi atau dimensi, kadang terorganisasi dan berada dalam regulasi para elitenya, tetapi tidak jarang meluas ke segala arah dan tidak sepenuhnya terkendali sesuai dengan relasi para tokohnya, situasi yang dihadapi, dan kondisi-kondisi yang begitu kompleks.

Gerakan sosial (social movements) menurut Turner dan Killian sebagaimana dikutip Mario Diani (2000) ialah : "a collectivity acting with some continuity to promote or resist a change in the society or organisation of which it is part", yakni suatu tindakan kolektif berkelanjutan untuk mendorong atau menghambat perubahan dalam masyarakat atau organisasi yang menjadi bagian dari masyarakat itu. Manifestasi gerakan sosial, selain memiliki bentuk-bentuk gerakan yang tidak melembaga, juga merupakan gerakan yang terorganisasi, berkelanjutan, dan tantangan kesadaran-diri yang menunjukan bagian identitas dari para pelakunya (Diani., hal. 158). Gerakan sosial dimana pun sering tampil dalam berbagai macam kecenderungan, bahkan tidak jarang bersifat antagonis dan di belakang hari menimbulkan banyak penafsiran dan kontroversi.

Demikian pula dengan gerakan keagamaan sebagai salah satu bentuk gerakan sosial tumbuh dalam kompleksitas sosiologis yang tidak mudah untuk digambarkan secara sederhana. Gerakan keagamaan (religious movements) sebagai salah satu fenomena keagamaan tentu tidak lepas dari dimensi agama itu sendiri yaitu keyakinan, simbol, praktek, dan organisasi (Hadden, 1992). Aspek gerakannya meliputi keyakinan (beliefs), nilai-nilai (values), bentuk organisasi (forms of organization), cara-cara aktivitas (kinds of activity), tipetipe keterlibatan (types of participation), reaksi-reaksi sosial (societal reactions), dan hubungan-hubungan agen pelaku atau relations with agencies (Beckford, 2003). Mengingat agama dan gerakan keagamaan itu hadir di tengah-tengah pergumulan masyarakat dalam menghadapi persoalan yang dipandang memerlukan respons, maka gerakan keagamaan di mana pun tidak hanya bersentuhan dengan aspek-aspek ajaran agama belaka tetapi juga berpautan dengan aspek-aspek yang bersifat kemasyarakatan secara umum seperti politik, ekonomi, sehingga menjadi suatu fenomena yang kompleks.

Gerakan keagamaan (religious movements) atau disebut pula gerakan sosialkeagamaan (socio-religious movements) pada umumnya muncul dalam bentuk gerakan revitalisasi dan gerakan millenari. Gerakan revitalisasi (revitalization move- 
UNISIA, Vol. XXXI No. 69 September 2008

ments), ialah gerakan keagamaan yang berupaya untuk menciptakan eksistensi yang baru atau yang "direvitalisasi", yang dipandang tepat untuk kondisi saat ini. Sedangkan gerakan millenari (millenary movements), yaitu suatu gerakan keagamaan untuk mengantisipasi tibanya suatu masa seribu tahun (millennium), suatu masa yang diyakini akan penuh kedamaian, harmoni, dan makmur, dengan hadirnya pemimpin kharismatik yang dipandang sebagai messias (ratu adil).

Gerakan revitalisasi atau millenari tumbuh dalam kondisi-kondisi ketegangan atau krisis sosial yang ekstrim. Sebutlah kondisi disorientasi sosial dalam kehidupan masyarakat tradisional akibat perubahan sosial yang cepat, perubahan kehidupan penduduk pribumi akibat penjajahan, perang, dan invasi kebudayaan asing; kondisi ketertindasan dan eksploitasi yang melampaui batas-batas yang tidak dapat ditoleransi. Dalam kondisi-kondisi semacam itu manusia atau masyarakat mengalami kebingungan untuk bertindak, sementara cara-cara atau jalan sekuler yang selama ini ada tidak mampu menangani berbagai ketegangan sosial yang terjadi secara ekstrim tersebut. Dalam kondisi yang demikian itulah muncul gerakan-gerakan keagamaan baik yang murni keagamaan maupun berkombinasi dengan politik, yang bergerak secara radikal dan militan (Sanderson, 1995).

Gerakan keagamaan hadir dalam corak eksogenesis (exogenous religius) yang berusaha untuk mengubah keadaan lingkungan sosial-kultural tempat umat beragama yang bersangkutan berada, juga bercorak generatif (generative religious) sebagaimana yang bersifat "cargo cult" (pemujaan barang), "messianic movements" (gerakan mesianis), "nativistic movements" (gerakan navitistik, kembali ke agama asal), dan "revitalization movements" atau gerakan revitalisasi (Hadden, 1992). Kondisi struktural dan kultural yang dianggap krisis bagi para pemeluk agama atau kelompokkelompok sektarian lainnya dapat membentuk pola politik kehidupan (life politics) dan peneguhan identitas diri (self-identity) yang hingga batas tertentu melahirkan kecenderungan sikap radikal dan fundamental sebagaimana tercermin dalam gerakan tandingan dan perlawanan (Giddens, 1994).

Gerakan keagamaan, sebagaimana pada umumnya gerakan sosial yang radikal, tumbuh sebagai reaksi keras terhadap struktur yang dipandang tidak adil dan mengancam eksistensi. Menurut perspektif ketegangan struktural sebagaimana dikembangkan TR Gurr (1970), bahwa suatu gerakan sosial terjadi ditandai dengan adanya kemarahan dan keputusasaan yang melahirkan gerak emosional yang sedemikian rupa yang disebabkan oleh adanya ketegangan sosial pada level makro dalam masyarakat (Mirsel, 2004). Ketegangan dan perlawanan dapat dilakukan dalam hubungannya dengan antar kekuatan atau kelompok dalam masyarakat yang dianggap menyimpang atau menjadi ancaman. Di pihak lain dapat lebih luas seperti gerakan sosial untuk melawan negara, termasuk melawan penjajah asing yang mengancam eksistensi bangsa atau masyarakat setempat. Dalam menghadapi kondisi struktur yang mengancam itu, maka pada skala yang lebih luas suatu gerakan sosial termasuk gerakan keagamaan dapat berkembang menjadi gerakan revolusi atau gerakan yang bersifat chaos, yang keluar dari norma-norma kelaziman yang berlaku dalam keadaan normal.

\section{Gerakan Purifikasi}

Gerakan Paderi (1821-1838) maupun gerakan "kaum putih" (gerakan Islam 
Purifikasi Islam dalam Gerakan Padri...; Haedar Nashir

mazhab Hambali atau gerakan Wahhabi) di Minangkabau yang berkembang sebelumnya (1803-1807) di bawah kepemimpinan Tuantu Nan Rentjeh, dan kemudian tokoh-tokoh lainnya seperti Haji Miskin, Haji Piobang, Haji Sumanik, Tuanku Imam Bonjol (Petro Syarif), Tuantu Rao, dan lain-lain dalam konteks gerakan keagamaan maupun gerakan rakyat memang memiliki watak yang puritan. Puritanisme dalam Islam maupun agama pada umumnya selalu dikaitkan dengan paham dan praktik keagamaan yang ingin kembali pada agama yang dipandang atau diyakini murni sesuai sumbernya yakni Al-Quran dan Sunnah Nabi tanpa tercampur-baur dengan apapun seperti syrik, bid'ah, dan khurafat.

Kelompok puritan sering dideskripsikan atau dikaitkan dengan istilah fundamentalis, militan, ekstrimis, radikal, fanatik, jihadis, dan bahkan Islamis. Pandangan puritan dalam Islam ditandai oleh ciri yang menonjol kelompok ini yang dalam keyakinannya menganut paham absolutisme dan tak kenal kompromi dalam beragama. Dalam banyak hal kelompok puritan cenderung menjadi puris, yakni seseorang atau sekelompok orang yang tidak toleran terhadap berbagai sudut pandang yang berkompetisi dan memandang realitas pluralis sebagai satu bentuk kontaminasi atas kebenaran sejati (El Fadl, 2005: 29).

Dalam gerakan Padri dengan semangat pembaruan kembali kepada Islam yang murni atau aseli sebagaimana ciri kaum Wahhabi atau Salafi, memang sangat kentara. Sjafnir Aboe Naim mempertegas watak puritanisme gerakan Padri yang berwatak Wahhabi itu sebagai berikut:

"Misi mereka adalah membersihkan berbagai pengaruh adat yang berlawanan dengan ajaran Islam. Ide ini timbul ketika mereka berkenalan dengan ajaran kaum Wahabi di Makah saat mereka menunaikan ibadah haji. Target mereka tuju ialah puritanisme agama Islam secara menyeluruh, yakni ketaatan mutlak terhadap agama, shalat lima waktu, tidak merokok, dan berjudi serta menyabung ayam." (Marajo, 2008: 48).

Puritanisme agama baik di Sumatra Barat maupun di sejumlah wilayah di Indonesia pada umumnya berhadapan dengan tradisi atau adat istiadat khususnya yang dilakukan oleh kalangan Islam tradisional atau lokal yang dianggap bertentangan dengan ajaran Islam. Kecenderungan puritan sebenarnya tidaklah tunggal tetapi terentang dari yang keras atau radikal hingga lunak atau moderat. Sebagai contoh, lahirnya gerakan modernisme/reformisme Islam awal abad ke-20 yang sering disebut pula sebagai gerakam "pemurnian Islam" atau Revivalisme Islam sebagaimana ditunjukkan oleh Muhammadiyah dan Persatuan Islam, menurut Deliar Noer kendati keduanya sama-sama mengajak "Kembali kepada AI-Quran dan As-Sunnah" dalam bentuk gerakan pembaruan Islam atau Islam modern, tetapi Muhammadiyah tampak lebih moderat atau lunak sedangkan Persatuan Islam lebih keras (Noer, 1996: 320). Dalam kelompok yang sama seperti dalam Muhammadiyah misalnya, bahkan antara satu wilayah atau daerah juga memiliki kecenderungan puritanisme yang tidak persis sama, meskipun seluruhnya berpedoman pada Keputusan Tarjih dalam menjalankan pokok-pokok ajaran Islam. Di sinilah rentang sikap puritanisme Islam pun memang tidaklah tunggal tetapi plural atau beragam.

Secara sosiologis sikap keagamaan yang puritan tersebut tidak sekadar intrinsik atau tumbuh di dalam dirinya sebagai suatu sistem keyakinan (belief syistem), yang biasanya melahirkan sikap keagamaan yang 
UNISIA, Vol. XXXI No. 69 September 2008

true-believers, yakni kelompok yang dengan keyakinan agamanya cenderung menjurus ke sikap fanatik-buta. Tetapi juga bertemali dengan realitas sosial yang tumbuh atau dihadapi di tengah-tengah kehidupan masyarakat. Dalam kaitan ini, maka gerakan Islam sebagaimana pada umumnya gerakan keagamaan kemudian berkembang menjadi bentuk sectarian respons (respon aliran) yang saling berhadapan dengan kelompok sosial lain dalam kehidupan masyarakat. Artinya kelahiran suatu gerakan keagamaan dengan beragam kecenderungannya, termasuk yang menunjukkan puritanisme yang keras, sering terkait atau terbentuk dalam dinamika dengan kelompok Islam atau kelompok sosial lainnya yang saling berlawanan, sehingga melahirkan konflik yang keras. Dalam kaitan dengan kelahiran gerakan Padri misalnya, terdapat gambaran respons sektarian yang digambarkan oleh Kutoyo sebagai berikut:

"Pada tahun 1803, golongan ulama merasa sudah cukup kuat. Mereka menamakan dirinya golongan Padri. Tuanku Nan Renceh diangkat sebagai pemimpin, bersama dengan haji Piobang dan kawan-kawannya. Mereka mulai melancarkan gerakan melarang tindakan yang tidak cocok dengan ajaran agama. Sebaliknya, golongan adat tidak mau menurut begitu saja. Mulailah timbul bentrokan di sana-sini. Peperangan besar tidak dapat dihindarkan. Pasukan Tuanku Nan Renceh bergerak cepat. Nagari Kamang yang subur dan merupakan gudang beras dapat dikuasainya. Daerah Kamang dijadikan pangkalan dan dalam waktu pendek seluruh Luhak Agam jatuh ke tangan Tuanku Nan Renceh pada tahun 1804. Di daerah Padri itu, pemerintahan dipegang oleh para ulama." (Kutoyo, 2004).
Setelah Kamang dan Agam jatuh ke pihak Padri, menyusul Luhak Limapuluh Koto. Namun di Luhak Tanah Datar, yang merupakan pusat kerajaan Minangkabau di Pagarruyung, terjadi perlawanan sengit dari golongan adat yang dipimpin para penghulu terhadap Padri. Dengan berpakaian serba putih, rambut kepala dicukur dan jenggot dibiarkan panjang, pasukan Padri mengobarkan semangat perang melawan kaum adat, sehingga terjadi pertempuran sengit dan akhirnya berujung dengan perundingan di Koto Tengah pada tahun 1809. Dalam perundingan itulah, di luar kontrol Tuanku Lintau (Saidi Muning) selaku Panglima Padri di Tanah Datar, terjadi tindakan pembunuhan oleh seorang perwira Padri terhadap anggota keluarga Raja Minangkabau, kendati Yang Dipertuan Raja Minangkabau dapat meloloskan diri ke Kuantan (Kutoyo). Dari peristiwa tersebut, jika kesahihannya dapat dipertanggungjawabkan, maka betapa gerakan keagamaan ketika mulai masuk ke kancah pergolakan tidak jarang atau kadang terjebak pada berbagai bentuk kekerasan yang di luar kendali pemimpin gerakan atau misi gerakan yang bersangkutan. Peristiwa seperti itu tentu saja sebagai bentuk dari fungsi manifes gerakan sosial-keagamaan yang tidak diharapkan, yang tidak dapat dibenarkan tetapi tidak jarang terjadi dalam sejarah pergolakan sosial.

Dalam kasus Padri yang lain, perbedaan antara Tuanku Nan Tuo yang menghendaki nir-kekerasan dengan Tuanku Nan Rentjeh yang membolehkan kekerasan sebagai jihad dalam hal menempuh purifikasi Islam terhadap sesama muslim merupakan contoh lain dari keragaman model gerakan. Karena perbedaan yang tajam itulah sampai harus ditempuh musyawarah dengan bantuan mediasi Tuanku Pamansiangan Nan Mudo sebagai penasihat (Marajo, 2008). 
Gerakan purifikasi Islam sebagaimana ditampilkan Padri dengan para tokohnya yang beragam, menunjukkan betapa tidak sederhananya suatu gerakan ketika mulai merambah dalam pergolakan yang bersifat fisik, sehingga melahirkan berbagai bentuk antagonis dan konflik yang di kemudian hari menyisakan wajah yang kompleks dari yang terang benderang hingga buram dalam sejarah suatu masyarakat atau bangsa. Pada titik inilah sejarah yang sudah terjadi tidak mudah untuk dihakimi atau divonis begitu saja, lebih-lebih setelah kurun waktu yang panjang dan dalam konteks ruang yang berbeda atau berubah seperti sekarang ini.

Gerakan purifikasi yang melekat dengan perjuangan Padri dan Islamisasi di Minangkabau memiliki keterkaitan dengan paham Wahabi (Wahhabi, Wahhabiyyah) yang memang cukup kuat di wilayah ini. Hamka mencatat bahwa Haji Miskin, Haji Piobang, dan Haji Sumanik adalah "pelopor paham Wahabi menjadi gerakan Padri atau Pidari di Minangkabau, yang pulang dari Makkah sekitar tahun 1803 atau setahun sebelumnya" (Hamka, 2008). Gerakan Wahabi yang mengikuti paham Muhammad bin Abdul Wahhab (1703-1792) pelopor pembaruan (pemurnian) Islam di Arab Saudi adalah "gerakan dakwah dengan menyeru umat mengakui dan melaksanakan ajaran keesaan Allah (tauhid), dalam zat, sifat dan perbuatan-Nya" (Marajo, 2008).

Gerakan Wahabi yang dikaitkan dengan praktik keagamaan Muhammad bin Abd Al-Wahhab memiliki watak dan orientasi keagaman yang puritan-konservatif dan cenderung keras dalam memberantas apa yang disebut dengan praktik keagamaan yaitu syirk, tahayul, bid'ah, dan khurafat. Gerakan ini secara umum sering pula dikaitkan dengan Salafiyah (Salafiyyah), yakni paham orang-orang yang meng- identifikasikan pemikiran mereka dengan pemikiran para Salaf. Gerakan ini ingin mengembalikan agama Islam kepada sumbernya yang murni yaitu Kitab Suci Qur'an dan Sunnah Nabi, dengan meninggalkan pertengkaran mazhab dan segala bid'ah yang disisipkan orang ke dalamnya (Abu Zahrah, 1996).

Salafiyah sebagai aliran paham (mazhab) atau gerakan, muncul pada abad ke-7 Hijriyah, yang dikembangkan oleh para ulama atau pengikut mazhab Hanbali (Ahmad Ibn Hanbal), yang menghidupkan aqidah ulama Salaf dan berusaha memerangi paham lainnya. Aliran ini dihidupkan dan dikembangkan dengan pemikiran pembaruan oleh Syaikh al-Islam, Ibn Taimiyyah. Pada abad ke-12 pemikiran Salafiyah itu muncul dan dihidupkan kembali di jazirah Arab oleh Muhammad Ibn Abdul Wahhab dengan pengikutnya kaum Wahabbi, yang menyebarluaskan paham ini dengan berkerjasama dalam kekuasaan Ibn Saud di jazirah Arab yang menampilkan gerakan yang sangat keras dan membangkitkan amarah sebagian ulama (Abu Zahrah, 1996).

Salafiyah memiliki karakter pemikiran antara lain, pertama, bahwa argumentasi pemikiran Islam harus jelas diambil dari AlQuran dan Al-Hadits. Kedua, penggunaan rasio atau akal pikiran harus sesuai dengan nash-nash yang shahih. Ketiga, seperti dikemukakan Ibnu Taymiyyah bahwa dalam konteks aqidah harus berdasarkan pada nash-nash saja. Nash atau teks ajaran Islam itu bersumber dari Allah, sedangkan rasio hanya berfungsi sebagai pembenar, yakni sebagai saksi (syahid) dan bukan sebagai penentu (hakimi), sehingga akal harus di bawah nash ajaran serta tidak boleh berdiri sendiri sebagai dalil, yakni akal sekadar untuk mendekatkan dengan kehendak nash ajaran. Pemikiran Salafiyah 
UNISIA, Vol. XXXI No. 69 September 2008

selain mengajak kembali pada Islam generasi awal yang dipandang murni, juga berusaha membangkitkan kembali dunia Islam dengan mengadakan pembaruan keagamaan dan reformasi moral sebagaimana dipelopori oleh Jamaluddin AlAfghani, Muhammad Abduh, dan Muhammad Rasyid Ridha, yang dikenal pula sebagai gerakan pembaruan. Gerakan Salafiyah juga memiliki orientasi keagamaan lainnya, yaitu mengecam praktik tarekat atau tasawuf karena dianggap melanggengkan keterbalakangan dan mengajarkan fatalisme atau kepasrahan hidup, serta praktik-praktik keagamaan yang mengajarkan pemujaan berlebihan terhadap wali, kuburan, dan orang-orang yang diangap suci (Panggabean, t.t.).

Dengan demikian, gerakan Wahabi di mana pun memang memiliki karakter yang puritan dan cenderung keras. Di Minangkabau gerakan Padri dengan orientasi paham Wahabi-nya boleh jadi memiliki akar kesejarahan dengan gerakan kembali pada syariat Islam pada kurun 1784-1790 sebagaimana dipelopori oleh Tuanku Nan Tuo dari Ampek Angkek dengan orientasi pada ortodoksi fikih dalam rangkaian corak Islamisasi abad ke-18 di wilayah ini (Marajo, 1998). Namun perlu dicatat, sebenarnya dalam temuan William Marsden, ketika mengupas tentang Kerajaan Minangkabau khususnya tentang agama di Ranah Minang, peneliti dan dokter Inggris yang tinggal selama delapan tahun di Bengkulu (sekitar tahun 1700-1708) ini menyatakan, "sejauh observasi saya, orangorang Melayu tidak nampak ekstrim terhadap agamanya seperti orang Islam di Barat." (Marsden, 2008).

Watak keras keagamaan dalam gerakan Padri yang dikaitkan dengan purifikasi ala Wahabi tentu tidak merupakan faktor tunggal. Dalam konteks gerakan baik
Wahabiyah maupun Padri sebagaimana terjadi di Minangkabau selalu terkait dengan relasi sosial-politik dan keagamaan yang tumbuh dan berkembang ketika gerakan ini lahir. Termasuk di dalamnya konflik paham dengan kalangan adat, yang menunjukkan orientasi baru dalam tatanan kemasyarakatan setempat di mana "ke-Islaman" jauh melampau "ke-Minangkabauan" yang menyertai paham baru melawan paham lama di wilayah ini (Koentjaraningrat,1976). Artinya, kecenderungan keras dalam keagamaan bertemali pula dengan realitas kemasyarakatan sekaligus paham yang dianut, sehingga bersifat kompleks. Hal yang lebih penting lagi, gerakan Padri dengan paham keagamaan yang puritan atau Wahabiyah itu, tidak dapat dilepaskan dari penghadapannya dan perlawanannya terhadap penjajahan Belanda kala itu. Perlawanan Padri yang demikian gigih dan luar biasa terhadap penjajah bahkan harus memperoleh apresiasi yang tinggi dan tidak dapat diabaikan, lebih dari sekadar persoalan gerakan purifikasi keagamaannya.

\section{Pembahasan}

\section{Melawan Penjajah}

Gerakan Padri sebagaimana gerakangerakan lokal di berbagai belahan bumi Nusantara pada periode perang kemerdekaan melawan penjajahan Belanda di samping penjajahan Portugis dan Inggris yang masuk ke kepulauan Nusantara, merupakan tonggak yang penting dalam sejarah Indonesia. Gerakan Padri menurut Sartono Kartodirdjo, selain berhasil dalam membersihkan agama Islam dari pengaruhpengaruh kebudayaan setempat yang dianggap menyalahi ajaran agama Islam yang ortodoks, juga merupakan kekuatan 
Purifikasi Islam dalam Gerakan Padri...; Haedar Nashir

mobilisasi yang besar dari berbagai wilayah kekuasaannya di ranah kerajaan Minangkabau untuk menggabungkan diri melawan penjajah. Lebih-lebih setelah gerakan Padri di bawah kepemimpinan Imam Bonjol dengan basis benteng Bonjolnya di Alam Panjang, karena itu Belanda, setelah kembali ke Minangkabau tahun 1816 yang sebelumnya dikuasai Inggris, mengerahkan segala kekuatannya untuk melumpuhkan Padri. Sartono mencatat sebagai berikut:

“... Dalam menghadapi perjuangan kaum Padri, Belanda lama kelamaan sadar bahwa pada hakikatnya gerakan itu tidak hanya mempertahankan kepentingan agama akan tetapi juga melakukan perlawanan terhadap penetrasi kolonial, sebagai ancaman terhadap kemerdekaan mereka. Proses pasifikasi berjalan lambat, bahkan sering kali Belanda terpaksa bersikap defensif karena kaum Padri mengadakan serangan-serangan ke daerah pantai. Belanda memandang pemerintahan kaum Padri menimbulkan suatu anarki, maka ada alasan untuk menjalankan "pasifikasinya"; yang jelas ialah bahwa gerakan menjalankan ekspansi ke jurusan Mandailing, tanah Batak, dan Riau sehingga "perang dalam" (internal war) berkobar; maka timbul situasi yang banyak mengakibatkan penderitaan. Bagi penguasa kolonial konflik dan perpecahan memberi dalih untuk menjalankan intervensinya dan menanam pengaruhnya." (Kartodirdjo, 1993).

Kendati sejak ditandatangani perjanjian Bonjol pada awal tahun 1824 dan dengan berbagai tipu muslihat Belanda terhadap Padri, tetapi perlawanan gerakan ini terhadap penjajah terus berlangsung dan tidak mudah dipadamkan (Kartodirdjo,1993).
Politik Belanda mengikuti pola lama, yakni cenderung memihak yang lebih "lunak" dan mau bekerjasama dengan Belanda, sebaliknya keras dan tidak memberi ruang dan bahkan menggunakan segala macam cara untuk menumpas gerakan-gerakan yang keras seperti Padri. Dalam posisi yang demikian, pihak Padri kadang berjuang segitiga yaitu, internal melawan kaum adat dan sekaligus melawan penjajah Belanda yang memiliki strategi canggih dalam memecah-belah dan memanfaatkan situasi, sambil tidak segan-segan melakukan tipu muslihat. Perlawanan Padri di bawah Tuanku Imam Bonjol yang tidak mengenal menyerah dalam usianya ke-92 tahun, berakhir setelah Benteng Bonjol jatuh tanggal 16 Agustus 1837, dan dengan tipu muslihat dengan mengatasnamakan ajakan berunding maka Imam Bonjol pun ditangkap di Palupuh secara tidak kesatria (Kutoyo,2003).

Tuanku Imam Bonjol karena demikian kuat ancaman pengaruhnya, bahkan setelah dipenjara pun harus dipindah-pindah dari Bukittinggi ke Padang, terus ke Cianjur, Ambon, dan akhirnya ke Manado hingga wafat pada 8 November 1839 dalam kesendirian jauh dari kampung halaman ranah tempat dia dan seluruh kekuatan gerakan Padri berjuang melawan penjajah. Atas jasa dan perjuangannya, Tuanku Imam Bonjol oleh Pemerintah Republik Indonesia kemudian diangkat menjadi Pahlawan Nasional.

\section{Penutup}

Sejarah Minangkabau dengan gerakan Padri dan para tokohnya yang menonjol seperti Tuanku Nan Tuo, Tuanku Nan Rentjeh, Tuangku Imam Bonjol, Tuanku Rao, Haji Miskin, Haji Piobang, Haji Sumanik, dan lain-lain merupakan diorama yang penuh 
UNISIA, Vol. XXXI No. 69 September 2008

warna dan tidak dapat dilukiskan secara parsial atau linier. Gerakan Padri dengan kontroversinya yang terlibat dalam konflik internal dengan kekuatan adat, ekspansi ke Tanah Batak, dan purifikasi Islamnya yang dihadirkan secara keras tumbuh dan berkembang dalam ragam situasi sosiologis yang kompleks. Pertama, orientasi paham Wahabi yang memang berkarakter puritan dan lebih keras. Kedua, kondisi sosiologis masyarakat Minangkabau yang dipandang tidak sejalan dengan paham keagamaan yang tidak menghendaki praktik syirk, khurafat, bid'ah, dan hal-hal yang bertentangan dengan ajaran Islam. Ketiga, watak hegemoni kekuasaan dan gerakan di mana pun yang bersifat ekspansionistik, lebih-lebih yang bersenyawa dengan misi keagamaan yang bersifat puritan. Keempat, yang sifatnya lebih luas dan struktural, yakni perlawanan terhadap penjajah yang sifatnya hidup-mati dan memerlukan mobilisasi sosial-politik yang besar-besaran.

Khusus yang berkaitan dengan purifikasi Islam yang bercorak Wahabiyah atau Wahabi yang menyertai gerakan Padri dan para tokohnya, secara niscaya merupakan bagian dari matarantai sejarah Islam abad ke-18 dan ke-19 ketika gerakan pembaruan Islam dari Timur Tengah yang dipelopori oleh Ibn Taimiyyah, Muhammad bin Abdul Wahhab, Jamaluddin Al-Afghani, Muhammad Abduh, Muhammad Rasyid Ridha, dan lain-lain meluas ke negeri-negeri Islam atau berpenduduk Muslim. Ditambah dengan kondisi sosiologis yang bersifat domestik seperti konflik dengan kaum tradisional atau golongan adat, gerakan purifikasi Islam tersebut mengalami masifikasi yang luas dan kadang berwatak keras. Lebih-lebih ketika harus berhadapan dan melawan penjajahan baik di negerinegeri Islam maupun di kepulauan Nusantara termasuk di Minangkabau, maka gerakan pemurnian agama sebagaimana ditunjukkan Padri maka karakter dan gerakan yang cenderung keras itu memperoleh ruang sosial-politik yang semakin absah.

Sejarah dengan warna diakroniknya yang penuh rentangan termasuk yang ditampilkan gerakan Padri dan para tokohnya di Minangkabau, sebagaimana pada umumnya di belahan dunia, selalu memberikan inspirasi, evalusasi, sekaligus menjadi ibrah atau pelajaran berharga bagi generasi berikutnya. Pelajaran terpenting bagi generasi saat ini dan ke depan ialah bagaimana perjuangan untuk membela Tanah Air dilakukan dengan sepenuh pengorbanan, bahkan dengan jiwa sekalipun. Generasi saat ini perlu belajar tentang membela bangsa dan negara dengan penuh karakter dan idealisme, bukan hanya menikmati hasil para pahlawan dan pejuang di masa lampau yang telah berkorban hidup-mati. Lebih-lebih ketika bangsa Indonesia saat ini tengah bergumul dengan berbagai persoalan domestik yang berat di tengah hegemoni neo-kolonialisme dan neo-imperialisme global yang mencengkeram. Sungguh diperlukan generasi bangsa yang memiliki idealisme dan karakter yang kuat sebagaimana dicontohkan oleh para pahlawan dan pejuang kemerdekaan di masa lampau.

Khusus yang berkaitan dengan gerakan pemurnian atau purifikasi keagamaan maka dalam menghadapi berbagai persoalan keutaman, kebangsaan, dan dunia kemanusiaan saat ini yang begitu kompleks; maka diperlukan pandangan ke depan yang lebih transformasional. Islam dengan pesan kerisalahannya sebagai agama pembawa misi rahmatan lil-'alamin (QS Al-Anbiya: 107), baik dengan watak pemurnian maupun pembaruan, perlu hadir lebih dinamis dan pro-kehidupan agar tampil 
Purifikasi Islam dalam Gerakan Padri...; Haedar Nashir

menjadi agama dan peradaban alternatif di dunia pos-modern saat ini. Islam harus tampil bukan sekadar dalam gerakan yang mengembangkan sikap "al-jihad li almuaradhah" (perjuangan melawan) sebagaimana ditunjukkan oleh para pejuang di masa lampau atau ketika menghadapi musuh, tetapi yang lebih proaktif harus menampilkan "al-jihad li al-muwajahah" (perjuangan untuk menghadapi kehidupan) yang menampilkan alternatif baru yang bangunan fundamentalnya menjulang kokoh ke langit, sekaligus mampu menjadi agama bagi kehidupan di bumi yang nyata.

Model pemahaman puritanisme dengan berbagai variannya yang konservatisme tanpa penafsiran ulang atau transformasi baru atas teks dan realitas yang dihadapi dalam menghadapi dunia saat ini dan ke depan yang multikompleks hanya melahirkan sikap anti-kemajuan dan memusuhi setiap pemikiran yang berkembang tanpa alternatif. Absolutisme paham keagamaan tanpa sikap cerdas, arif, dan transformatif bahkan dapat mendorong kecenderungan memutlakan kebenaran sendiri dan tidak tertutup kemungkinan mendorong kekerasan atasnama agama. Sementara dunia kemanusiaan dengan berbagai problematikanya berkembang sedemikian rupa yang memerlukan pandangan Islam yang serba melampaui dan tidak terjebak pada ekstrimitas. Islam harus hadir sebagai Agama Langit sekaligus sebagai Agama Bumi, sehingga mampu menampilkan peradaban yang terbaik sekaligus menjadi rahmat bagi semesta kehidupan. Dengan gerakan Islam yang kokoh orientasi "habl min Allah" dan "habl min al-nas" yang dimilikinya (QS Ali Imran: 112), maka umat Islam di mana pun akan hadir sebagai alternatif peradaban dan peradaban alternatif yang unggul dan mencerahkan.

\section{Pustaka}

Zahrah,Abu, Imam Muhammad. 1996. Aliran Politik Dan 'Aqidah Dalam Islam, terjemahan Abd. Rahman Dahlan dan Ahmad Qarib, Jakarta, Logos.

Atjeh, Aboebakar. 1970. Salaf: Muhii Atsaris Salaf, Gerakan Salafijah di Indonesia, Jakarta: Permata.

Beckford, James A. 2003. Social Theory \& Religion, New York: Cambridge University Press.

Datuk Marajo, Sjafnir Aboe Naim. 2008. 200 Tahun Tuanku Imam Bonjol: Sejarah Intelektual Islami di Minangkabau 1784-1832, Yogyakarta: Penerbit Suara Muhammadiyah.

El Fadl, Khaled Abou. 2005. Selamatkan Islam dari Muslim Puritan, Jakarta: Serambi.

Giddens, Anthony. 1994. Beyond Left And Right: The Future Of Radical Politics, Cambridge: Polity Press.

Hadden, Jeffrey K.. 1992. "Reeligious Movements" dalam Edgar F. Borgatta and Marie L. Borgatta, Encyclopedia Of Sociology, Volume 3, New York: Macmillan Publishing Company.

Hamka. 2008. Antara Fakta Dan Khayal Tuanku Ra, Yogyakarta: Suara Muhammadiyah.

Harahap, Basyral Hamidy. 2007. Greget Tuanku Rao, Jakarta: Komunitas Bambu. 
UNISIA, Vol. XXXI No. 69 September 2008

Kartodirdjo, Sartono. 1993. Pengantar Sejarah Indonesia Baru: 1500-1900 Dari Imperium Sampai Imperium, Jilid 1, Jakarta: Gramedia.

Koentjaraningrat. 1976. Manusia dan Kebudayaan di Indonesia.Jakarta: Jambatan.

Kutoyo, Sutrisno dan Mardanas Safwan. 2003. Seri Pahlawan Tuanku Imam Bonjol, Jakarta: Mutiara Sumber Widya.

Mario Diani, 2000, "The Concept of Social Movement", dalam Kate Nash, editor, Readings in Contemporary Political Sociology, Malden-Massachutes: Blackwell Publishers.

Marsden, William. 2008. Sejarah Sumatra, terjemahan, Jakarta: Komunitas Bambu.
Mirsel, Robert, 2004. Teori Pergerakan Kemasyarakatan, Yogyakarta, Insist.

Noer, Deliar, 1996. Gerakan Moderen Islam di Indonesia 1990-1942, Jakarta, LP3ES.

Panggabean, Samsu Rizal, t.t., "Organisasi dan Gerakan Islam", dalam Taufik Abdullah dkk., Ensiklopedi Tematis Dunia Islam, Jilid 6 .Jakarta: Ichtiar Baru Van Hoeve.

Parlindungan, Mangaradja Onggang, 2007, Tuanku Rao, Yogyakarta: LKiS.

Sanderson, Stephen K., 1995. Sosiologi Makro: Sebuah Pendekatan Terhadap Realitas Sosial, Jakarta: Rajawali Press. 